\title{
HPLC-DAD Analysis, Antileishmanial, Antiproliferative, and Antibacterial Activities of Lacistema pubescens: An Amazonian Medicinal Plant
}

\author{
Josiane Mello da Silva, ${ }^{1}$ Luciana Maria Ribeiro Antinarelli, ${ }^{2}$ \\ Nícolas de Castro Campos Pinto, ${ }^{1}$ Elaine Soares Coimbra, ${ }^{2}$ \\ Elaine Maria de Souza-Fagundes, ${ }^{3}$ Antônia Ribeiro, ${ }^{1}$ and Elita Scio ${ }^{1}$ \\ ${ }^{1}$ Bioactive Natural Products Laboratory, Department of Biochemistry, Biological Sciences Institute, Federal University of Juiz de Fora, \\ José Lourenço Kelmer, s/n, São Pedro, 36036-900 Juiz de Fora, MG, Brazil \\ ${ }^{2}$ Department of Parasitology, Microbiology and Immunology, Biological Sciences Institute, Federal University of Juiz de Fora, \\ Juiz de Fora, MG, Brazil \\ ${ }^{3}$ Department of Physiology and Biophysics, Biological Sciences Institute, Federal University of Minas Gerais, Avenida Antônio Carlos, \\ 6627, Pampulha, 31270-901 Belo Horizonte, MG, Brazil
}

Correspondence should be addressed to Elita Scio; elita.scio@uff.edu.br

Received 13 February 2014; Revised 27 June 2014; Accepted 17 July 2014; Published 7 August 2014

Academic Editor: Fátima Ribeiro-Dias

Copyright (C) 2014 Josiane Mello da Silva et al. This is an open access article distributed under the Creative Commons Attribution License, which permits unrestricted use, distribution, and reproduction in any medium, provided the original work is properly cited.

\begin{abstract}
Species of the genus Lacistema are traditionally used by Brazilian and Peruvian indigenous communities. The present study investigated the in vitro antileishmanial activity against several Leishmania species, cytotoxicity in murine peritoneal macrophages, antiproliferative activity against HL60 and Jurkat cells, and antibacterial activities against seven bacteria strains of the aerial parts of the methanolic crude extract and fractions of Lacistema pubescens. In addition, their chemical profile was also evaluated. Hexane fraction showed the most significant $\mathrm{IC}_{50}$ values against all promastigotes of Leishmania species tested, except for L. chagasi $\left(\mathrm{IC}_{50}=\right.$ $4.2 \mu \mathrm{g} / \mathrm{mL}$ for L. major and $\mathrm{IC}_{50}=3.5 \mu \mathrm{g} / \mathrm{mL}$ for L. amazonensis). This fraction also exhibited a strong activity against amastigotes of $L$. amazonensis $\left(\mathrm{IC}_{50}=6.9 \mu \mathrm{g} / \mathrm{mL}\right)$. The antiproliferative activity was also observed for methanolic extract and hexane fraction with $\mathrm{IC}_{50}=47.2 \mu \mathrm{g} / \mathrm{mL}$ and $\mathrm{IC}_{50}=39.7 \mu \mathrm{g} / \mathrm{mL}$ for HL60, respectively. Regarding the antimicrobial activity, the overall antibacterial activity was not very significative. Phytol and sitosterol were identified in the methanolic extract. Additionally, previous studies also revealed the presence of those compounds in the hexane fraction. Among other compounds, phytol and sitosterol were probably involved in the antileishmanial and cytotoxicity activities observed in this study.
\end{abstract}

\section{Introduction}

The family Lacistemataceae is represented by the genera Lacistema and Lozania with about 11 and 4 species, respectively [1]. Some species of Lacistema are traditionally used by Brazilian indigenous from Amazon against rheumatism, vomiting, dysentery, body aches, and fever [2-4]. A list of the Peruvian Amazonian plants used for medicinal purposes also mentioned Lacistema sp. to combat rheumatism and as antipyretic [4]. In addition, some studies had shown the potential pharmacological properties of some Lacistema species such as antiplasmodial [4], antimutagenic [5], antifungal [6], and antiviral [7].

Originally from Brazil, Lacistema pubescens Mart. is widely distributed in other countries such as Bolivia, Guyana, and Venezuela. In Brazil, it is known as "espeto vermelho," "canela vermelha" $[8,9]$ "sabãozinho" [10], and "cafezinho" [11]. Recently, it was evidenced that the leaves of L. pubescens present a potential antioxidant capacity, possibly correlated to phenolic compounds detected in this species [12]. Also, the antinociceptive and anti-inflammatory activity of the hexane fraction of $L$. pubescens leaves were reported [13] confirming 
the popular use of the genus by indigenous communities. This study also resulted in the identification of fatty acids such as palmitic acid and stearic and linoleic acid in this fraction. Tocopherol, the diterpene phytol, and the sterol sitosterol were also identified.

To the best of our knowledge, apart from those preliminary reports on the chemical composition and pharmacological activities of $L$. pubescens $[12,13]$, no other reports on the phytochemical or bioactivity of this species are available to date. So, the present study was conducted to evaluate the in vitro antibacterial, antiproliferative, and antileishmanial properties and to identify some compounds of the methanolic extract of L. pubescens.

\section{Materials and Methods}

Plant Material. Lacistema pubescens Mart. leaves were collected in Juiz de Fora, State of Minas Gerais, Brazil, in December 2011 and identified by Dra. Fátima Regina Gonçalves Salimena from the Department of Botany of the Institute of Biological Sciences (Federal University of Juiz de Fora). A voucher specimen (CESJ 49751) has been deposited at the Leopoldo Krieger Herbarium of the Federal University of Juiz de Fora.

Preparation of the Methanolic Extract and Fractions. The dried leaves $(375 \mathrm{~g})$ were powdered and macerated with methanol $(5 \times 300 \mathrm{~mL})$ for five days at room temperature. The methanolic extract $(57 \mathrm{~g})$, after removal of solvent, was dissolved in $\mathrm{MeOH}-\mathrm{H}_{2} \mathrm{O}(8: 2)$ and partitioned with hexane and ethyl acetate to obtain hexane $(16 \mathrm{~g})$, ethyl acetate $(7 \mathrm{~g})$, and the remaining hydromethanolic fractions $(5 \mathrm{~g})$. The extract and fractions were then concentrated using a rotary evaporator under reduced pressure and kept in tightly stoppered bottle under refrigeration until being used for the biological testing.

High Pressure Liquid Chromatography (HPLC) Analysis. HPLC analysis with a DAD detector and an automatic injector (Agilent Technologies 1200 Series, USA) was performed for methanolic extract, ethyl acetate, and hydromethanolic fractions. The column employed was a Zorbax SB-18; 250 $\times 4.6 \mathrm{~mm}, 5 \mu \mathrm{m}$ particle size. The mobile phase applied was 0-30 min, HPLC-grade methanol-acetonitrile $(70: 30 \mathrm{v} / \mathrm{v})$. The sample volume was $20 \mu \mathrm{L}(1 \mathrm{mg} / \mathrm{mL})$, the flow rate was $1 \mathrm{~mL} / \mathrm{min}$, and the temperature was maintained at $25^{\circ} \mathrm{C}$ during the analysis. Detection was performed at $210 \mathrm{~nm}$. Phytol and sitosterol standards (Sigma-Aldrich, USA) were used in this experiment as markers under the same conditions used for the samples.

In Vitro Antileishmanial Activity Evaluation. Leishmania major (MRHO/SU/59/P), L. braziliensis (MHOM/BR/ M2903), L. chagasi (MHOM/BR/PP75), and L. amazonensis (IFLA/BR/67/PH8) promastigotes were used for in vitro screening.

Antipromastigote Assays. The antileishmanial activity was determined by colorimetric 3-(4,5-dimethylthiazol-2-yl)-2,5diphenyltetrazolium bromide (MTT, Sigma-Aldrich, USA) method [14]. Briefly, promastigotes of L. amazonensis were cultured in the Warren's medium (brain heart infusion plush hemin and folic acid), promastigotes of L. braziliensis and L. major were maintained in BHI medium, and promastigotes of L. chagasi were maintained in medium 199, both supplemented with $10 \%$ fetal bovine serum at $24^{\circ} \mathrm{C}$. The screening was performed in 96-well microplates maintained at $24^{\circ} \mathrm{C}$. The samples tested were added at different concentrations (100 to $6.25 \mu \mathrm{g} / \mathrm{mL}$ ) after dilution in water or DMSO (dimethylsulfoxide), and the highest used concentration of DMSO was $0.8 \%(\mathrm{v} / \mathrm{v})$, which is not toxic to the parasites. Then, a parasite suspension from a logarithmic phase culture was suspended to yield 2 million parasites/well (L. amazonensis) or 3 million parasites/well (L. chagasi, L. major, and L. braziliensis) after Neubauer chamber counting. Controls with DMSO and without plant samples were performed. All samples were tested in triplicate, in three independent experiments. The viability of promastigotes was assayed after a three-day incubation period with addition of MTT. The reaction was stopped with $\mathrm{HCl}$ in isopropyl alcohol and the optical densities were evaluated in a spectrophotometer at $570 \mathrm{~nm}$. The results were expressed as the concentrations inhibiting parasite growth by $50 \%\left(\mathrm{IC}_{50}\right)$ calculated using a nonlinear regression curve, by using GraFit Version 5 software (Erithacus Software, Horley, UK). Amphotericin B (Cristalia, São Paulo, Brazil) was used as the standard drug (1.000 to $0.008 \mu \mathrm{g} / \mathrm{mL})$.

Antiamastigote Assays. Macrophages were obtained from the peritoneal cavity of BALB/c mice previously inoculated with $3 \%$ thioglycollate medium (Sigma-Aldrich, USA). Briefly, peritoneal macrophages were plated at $2 \times 10^{6}$ cells $/ \mathrm{mL}$ on coverslips (13 mm diameter) previously arranged in a 24-well plate in RPMI 1640 medium supplemented with 10\% inactivated FBS, and allowed to adhere for $24 \mathrm{~h}$ at $33^{\circ} \mathrm{C}$ in $5 \% \mathrm{CO}_{2}$. Adherent macrophages were infected with L. amazonensis (IFLA/BR/67/PH8) promastigotes in the stationary growth phase using a $1: 10$ ratio at $33^{\circ} \mathrm{C}$ for $4 \mathrm{~h}$. Noninternalized promastigotes were eliminated and solutions of test compounds were added (25.0 to $1.6 \mu \mathrm{g} / \mathrm{mL})$ and maintained at $33^{\circ} \mathrm{C} 5 \%$ $\mathrm{CO}_{2}$ for $72 \mathrm{~h}$. Slides were fixed and stained with Giemsa for parasite counting (optical microscopy, 1000x magnification). The parasite burden was evaluated was evaluated comparing the number of intracellular amastigotes in treated and untreated cultures (number of amastigotes in treated group/number of amastigotes in untreated group $\times 100)$. A minimum of 200 cells were counted (infected and uninfected macrophages). Miltefosine (Cayman Chemical Company, Michigan, USA) was used as the reference drug (1.000 to $0.039 \mu \mathrm{g} / \mathrm{mL})$. All procedures were performed in agreement with the Ethical Principles in Animal Research and according to protocols approved by the Ethical Committee of for Animal Research.

For statistical analysis, the $50 \%$ inhibitory concentration, that is, the minimum compound concentration that caused $50 \%$ reduction in survival of the amastigote and promastigote forms of Leishmania $\left(\mathrm{IC}_{50}\right)$, was carried out and the $95 \%$ confidence intervals were included, calculated by Litchtfiet and Wilcoxon method using the Probit. The graphs were 
plotted by the program GraphPad Prism 4 (GraphPad software, USA). The data were analyzed statistically using analysis of variance (ANOVA) followed by Dunnett post-test to compare all groups to the control group. Differences were regarded as significant when $P<0.0001\left({ }^{* * *}\right)$.

Cytotoxicity against Mammalian Cells. Mouse peritoneal macrophages were plated at $2 \times 10^{6}$ macrophages $/ \mathrm{mL}$ in 96 well culture plates and incubated for $72 \mathrm{~h}$ at $37^{\circ} \mathrm{C}$ in $5 \% \mathrm{CO}_{2}$ in RPMI 1640 medium containing 10\% fetal bovine serum and different concentrations of the test samples (150.0 to $9.4 \mu \mathrm{g} / \mathrm{mL}$ ) in $0.5 \%$ DMSO. The viability of the macrophages was determined with the MTT assay and was confirmed by comparing the morphology of the control group via light microscopy. $\mathrm{CC}_{50}$ values (50\% cytotoxicity concentration) were obtained by using GraFit Version 5 software. The cytotoxicity for macrophages and for amastigotes of L. amazonensis was compared using the selectivity index (SI), which was determined as the ratio between $\mathrm{CC}_{50}$ for macrophages and $\mathrm{IC}_{50}$ for parasites.

Cell Lines. HL60 cells (human promyelocytic leukemia HL-60 cells) and human immortalized lines of T lymphocyte (Jurkat cells) were a kind gift from Dr. Gustavo Amarante-Mendes (São Paulo University, Brazil). All lineages were cultivated in the logarithmic phase of growth in RPMI 1640 medium (Sigma-Aldrich, USA) supplemented with $100 \mathrm{U} / \mathrm{mL}$ penicillin and $100 \mu \mathrm{g} / \mathrm{mL}$ streptomycin enriched with $2 \mathrm{mM}$ of Lglutamine and $10 \%$ of fetal bovine serum (Gibco). All cultures were maintained at $37^{\circ} \mathrm{C}$ in a humidified incubator with $5 \%$ $\mathrm{CO}_{2}$.

Cytotoxic Effect against Human Tumor Cell Lines. The leukemia cell lines were cultured in 96-well plate at densities of 50,000 cells/well, in a final volume of $200 \mu \mathrm{L} /$ well. The plates were preincubated in a $5 \% \mathrm{CO}_{2} / 95 \%$ air-humidified atmosphere at $37^{\circ} \mathrm{C}$ for $24 \mathrm{~h}$ to allow adaptation of cells prior to the addition of the samples. The test samples were dissolved in DMSO and the half maximal inhibitory concentration $\left(\mathrm{IC}_{50}\right)$ was determined over a range of concentrations of a freshly prepared solution of the samples (100 to $6.25 \mu \mathrm{g} / \mathrm{mL}$ ). All cell cultures were incubated in a 5\% $\mathrm{CO}_{2} / 95 \%$ airhumidified atmosphere at $37^{\circ} \mathrm{C}$ for $48 \mathrm{~h}$. Cell viability was estimated by MTT assay [14]. The optical densities were measured with a spectrophotometer at $590 \mathrm{~nm}$. Control groups included treatment with $0.1 \%$ DMSO (negative control) and etoposide $14 \mu \mathrm{M}$ (positive control). All samples were tested in triplicate, in three independent experiments.

Antibacterial Assay. The samples were evaluated against a panel of bacteria strains, including Staphylococcus aureus (ATCC 6538), Pseudomonas aeruginosa (ATCC 15442), Shigella dysenteriae (ATCC 13313), Salmonella typhimurium (ATCC 13311), Escherichia coli (ATCC 10536), Enterococcus faecalis (ATCC 51299), and Enterobacter cloacae (ATCC 10699).

Serial Dilution Assay for Determination of the Minimal Inhibitory Concentration (MIC). The minimal inhibitory concentration (MIC) of the extract and its fractions was determined by using the broth microdilution technique [15]. MIC values were determined in Mueller Hinton broth (MHB). Bacteria were cultured overnight at $37^{\circ} \mathrm{C}$ for $24 \mathrm{~h}$ in BHI. Sample stock solutions were diluted from 1000 to $7.8 \mu \mathrm{g} / \mathrm{mL}$ (final volume $=80 \mu \mathrm{L}$ ) and a final DMSO concentration $\leq 1 \%$. Then, $\mathrm{MHB}(100 \mu \mathrm{L})$ was added into microplates. Finally, $20 \mu \mathrm{L}$ of $10^{8} \mathrm{CFU} / \mathrm{mL}$ (according to McFarland turbidity standards) of standardized bacterial suspensions was inoculated into microplates and the test was performed at a volume of $200 \mu \mathrm{L}$. Plates were incubated at $37^{\circ} \mathrm{C}$ for $24 \mathrm{~h}$. The same tests were performed simultaneously for growth control (MHB + bacteria) and sterility control (MHB + extract/fractions) and as positive control, chloramphenicol at concentrations from 100 to $0.78 \mu \mathrm{g} / \mathrm{mL}$. MIC was calculated as the lowest concentration which shows complete inhibition of the strain tested.

\section{Results and Discussion}

The HPLC chromatogram profile of the methanolic extract of L. pubescens was performed and two compounds were identified as phytol and sitosterol (Figure 1). Those compounds were not detected in ethyl acetate and hydromethanolic fractions (data not shown). Additionally, our previous studies also revealed the presence of those compounds in the hexane fraction [13].

The methanolic extract of $L$. pubescens leaves and its fractions were tested against promastigote forms of different Leishmania species which are responsible for various clinical manifestations, ranging from simple cutaneous form to severe visceral form. This is a widespread disease, affecting 12 million people around the world with about 1-2 million estimated new cases occurring every year [16]. The current treatment for all forms of clinical manifestation of leishmaniasis is based on pentavalent antimonials, amphotericin B, and Pentamidine. However, they are toxic, expensive, and difficult to administer and their use induces parasite resistance $[17,18]$.

For all bioassay, the $\mathrm{IC}_{50}$ values below $100 \mu \mathrm{g} / \mathrm{mL}$ were considered significant [19]. As demonstrated in Table 1, the methanolic extract and hexane fraction were potent against L. amazonensis, with $\mathrm{IC}_{50}=3.9$ and $3.5 \mu \mathrm{g} / \mathrm{mL}$, respectively. Hexane fraction also presented strong activity for $L$. major $\left(\mathrm{IC}_{50}=4.2 \mu \mathrm{g} / \mathrm{mL}\right)$, while methanolic extract was completely inactive. For L. braziliensis, those samples showed $\mathrm{IC}_{50}=17$ and $45.6 \mu \mathrm{g} / \mathrm{mL}$, respectively. Ethyl acetate and hydromethanolic fractions presented no antileishmanial activity. Neither the extract nor the fractions were active against $L$. chagasi promastigotes at the maximum concentration tested. Variations in sensitivity to several pure compounds and extracts against promastigotes of different Leishmania species have also been reported in previous studies [20-24]. Biochemical and molecular differences between Leishmania species including the pattern of glycosylation, enzymes as nucleotidases, and phosphomonoesterases, as well as the major lipophosphoglycan (LPG) present in surface of Leishmania sp., have been reported [25-27]. Comparison between the whole-genome expression patterns of L. major 


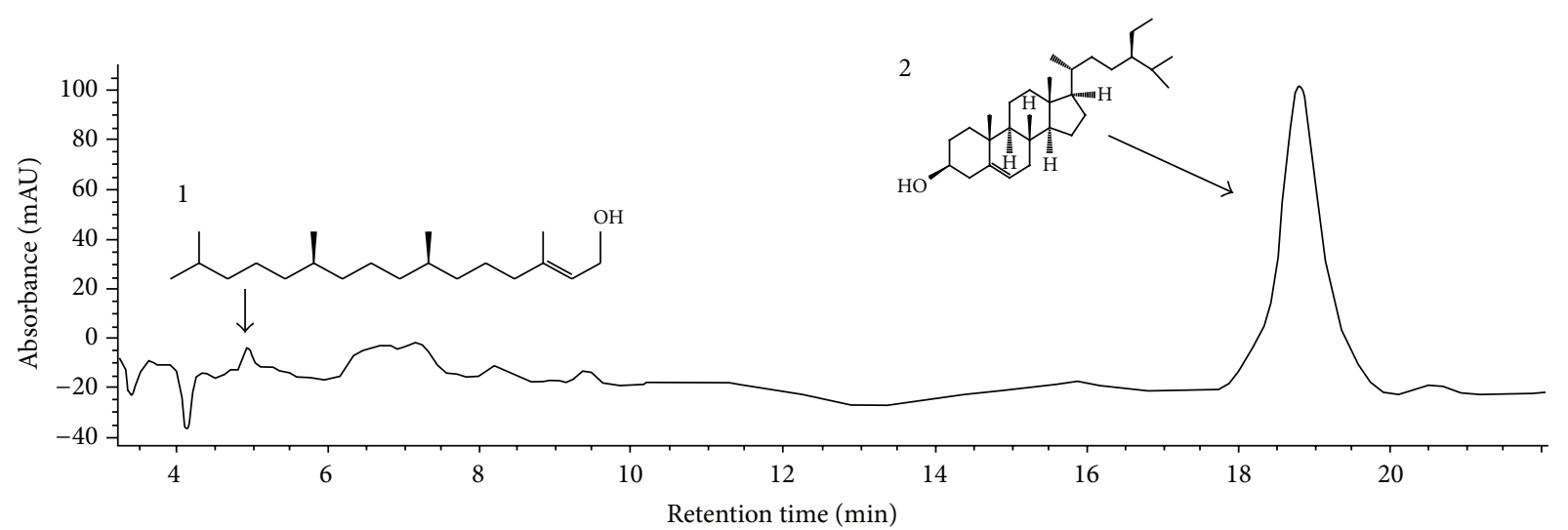

FIGURE 1: Chromatogram of methanolic extract of $L$. pubescens leaves. Peaks identified: 1 , phytol $(\mathrm{TR}=4.8 \mathrm{~min})$, and 2 , sitosterol (TR $=$ $18.5 \mathrm{~min})$. HPLC conditions: Zorbax SB-18 (250 mm $\times 4.6 \mathrm{~mm}$ i.d.; $5 \mu \mathrm{m})$; methanol-acetonitrile $(70: 30 \mathrm{v} / \mathrm{v}) ; 1.0 \mathrm{~mL} / \mathrm{min}$; injection volume, $20 \mu \mathrm{L} ; \mathrm{UV}$ detection at $210 \mathrm{~nm}$.

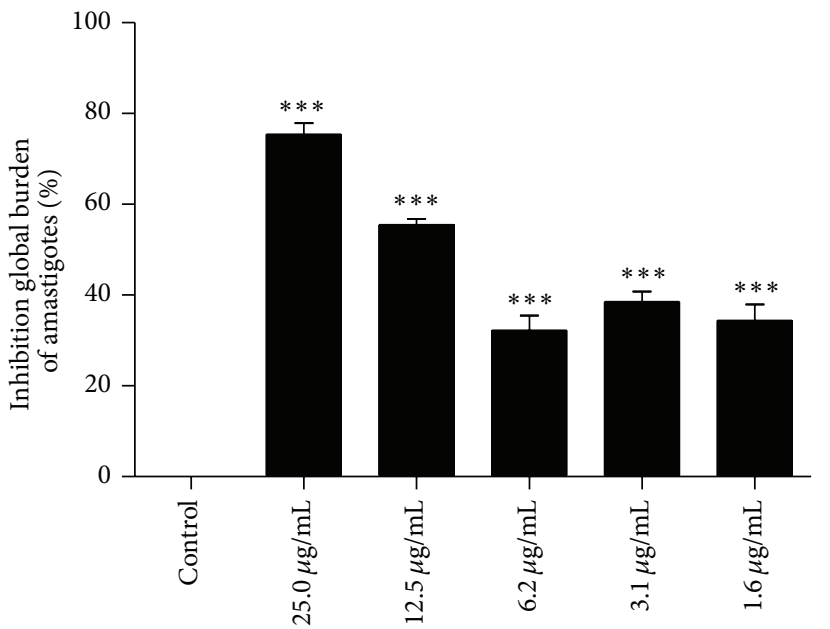

(a)

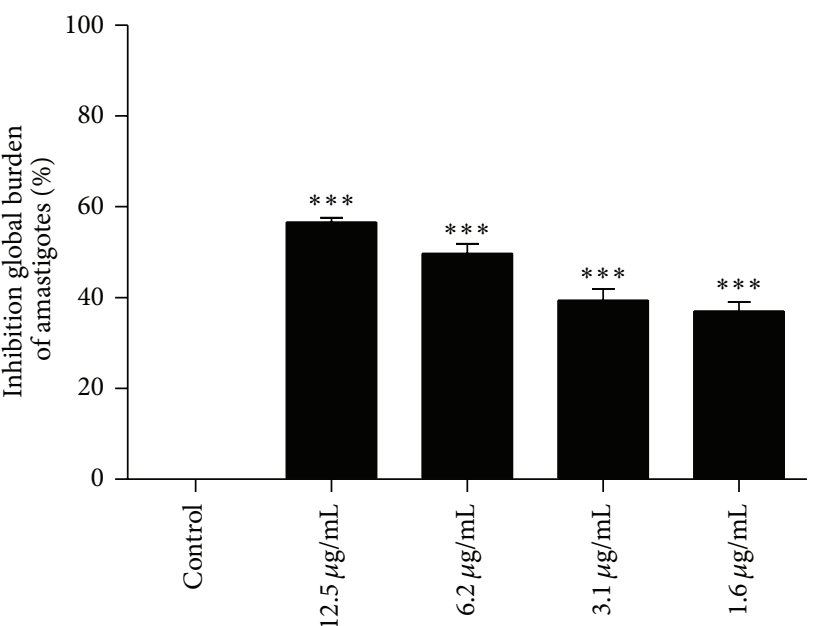

(b)

FIGURE 2: Effect of methanolic extracts (a) and hexane fraction (b) on intracellular amastigotes. Peritoneal macrophages previously infected with $L$. amazonensis promastigotes in the stationary growth phase were exposed to the samples for $72 \mathrm{~h}$. The parasite burden was evaluated comparing the number of intracellular amastigotes in treated and untreated cultures (control). All results were significant $\left({ }^{* * *} P<0.0001\right)$.

and L. infantum also showed some variations in genes involved in metabolism, cellular organization and biogenesis, transport and genes encoding unknown function [28]. Thus the variation in intrinsic sensitivity to several extracts is not surprising.

Promastigote forms of Leishmania were used as preliminary screening for antileishmanial activity. Subsequently, assays using amastigote forms were also performed. Intracellular amastigotes are considered the gold standard for antileishmanial in vitro evaluation, as this parasite forms are found in mammalian host, including the man, and are responsible for all clinical manifestations of leishmaniasis [29]. Leishmania amazonensis, the most sensitive Leishmania species in the antipromastigote tests (Table 1), was chosen for the antiamastigote assays. In this assay, the macrophages were efficiently infected (controls $=50 \%$ of infected macrophages, with 4.3 parasites/infected cells). In general, it was observed that the methanolic extract and hexane fraction of $L$. pubescens showed dose-dependent effect in the reduction of the number of intracellular parasites (Figure 2). Furthermore, as can be seen in Figure 2, hexane fraction showed a higher percentage of inhibition of global burden of amastigotes with $56.6,49.7,38.4$, and $37.1 \%(12.5,6.2,3.1$, and $1.6 \mu \mathrm{g} / \mathrm{mL}$, resp.). Methanolic extract also exhibited expressive activity with $75.4,55.5,32.3,38.5$, and $34.4 \%$ of inhibition of global burden $\left(25.0,12.5,6.2,3.1\right.$, and $1.6 \mu \mathrm{g} / \mathrm{mL}$, resp.). Furthermore, $\mathrm{IC}_{50}$ values for the hexane fraction and methanolic extract against L. amazonensis amastigotes was very low $(6.9$ and $8.1 \mu \mathrm{g} / \mathrm{mL}$, resp.) and highlighted the activity of those samples against intracellular form of the parasite (Table 2). Miltefosine, the reference drug, exhibited $\mathrm{IC}_{50}$ value of $3.9 \mu \mathrm{g} / \mathrm{mL}$.

Macrophages are the main host cell for Leishmania protozoa, so it is important to know the toxicity of the methanolic extract and hexane fraction of $L$. pubescens on 
TABLE 1: Antileishmanial and antiproliferative activity of the methanolic extract and fractions of L. pubescens.

\begin{tabular}{|c|c|c|c|c|c|c|}
\hline \multirow{3}{*}{ Samples } & \multicolumn{6}{|c|}{$\mathrm{IC}_{50}$ values $(\mu \mathrm{g} / \mathrm{mL})^{\mathrm{b}}$} \\
\hline & \multicolumn{4}{|c|}{ Antileishmanial activity (promastigote forms) ${ }^{\mathrm{a}}$} & \multicolumn{2}{|c|}{ Antiproliferative activity } \\
\hline & $\mathrm{La}$ & $\mathrm{Lb}$ & $\mathrm{Lm}$ & $\mathrm{Lc}$ & HL60 & Jurkat \\
\hline Methanolic extract & $\begin{array}{c}3.9 \\
( \pm 0.7)\end{array}$ & $\begin{array}{c}45.6 \\
( \pm 2.1)\end{array}$ & $>100$ & $>100$ & $\begin{array}{c}47.2 \\
( \pm 13.08)\end{array}$ & $>100$ \\
\hline Hexane & $\begin{array}{c}3.5 \\
( \pm 0.9)\end{array}$ & $\begin{array}{c}17.0 \\
( \pm 0.07)\end{array}$ & $\begin{array}{c}4.2 \\
( \pm 0.8)\end{array}$ & $>100$ & $\begin{array}{c}39.7 \\
( \pm 1.37)\end{array}$ & $>100$ \\
\hline Ethyl acetate & $>100$ & $>100$ & $>100$ & $>100$ & $>100$ & $>100$ \\
\hline Hydromethanol & $>100$ & $>100$ & $>100$ & $>100$ & $>100$ & $>100$ \\
\hline Amphotericin $\mathrm{B}^{\mathrm{c}}$ & $\begin{array}{c}0.4 \\
( \pm 0.05)\end{array}$ & $\begin{array}{c}0.30 \\
( \pm 0.09)\end{array}$ & $\begin{array}{c}0.3 \\
( \pm 0.09)\end{array}$ & $\begin{array}{c}1.9 \\
( \pm 0.25)\end{array}$ & - & - \\
\hline Etoposide $^{\mathrm{d}}$ & $-^{\mathrm{e}}$ & - & - & - & $\begin{array}{c}0.02 \\
( \pm 0.01)\end{array}$ & $\begin{array}{c}3.0 \\
( \pm 2.13)\end{array}$ \\
\hline
\end{tabular}

Organism key: ${ }^{\mathrm{a} L a:}$ Leishmania amazonensis; Lb: Leishmania braziliensis; Lm: Leishmania major; Lc: Leishmania chagasi.

${ }^{\mathrm{b}} \mathrm{IC}_{50}$ values (concentrations inhibiting cell growth by $50 \%$ ). Data are presented as median and $95 \%$ confidence interval (in parentheses).

${ }^{c, d}$ Control drug. ${ }^{e}$ ND: not done.

TABLE 2: Effect of the compounds on intracellular amastigotes of $L$. amazonensis and selectivity index.

\begin{tabular}{lccc}
\hline Samples & $\begin{array}{c}\text { Macrophages } \\
\mathrm{CC}_{50}(\mu \mathrm{g} / \mathrm{mL}) \\
(95 \% \text { C.I. })^{\mathrm{a}}\end{array}$ & $\begin{array}{c}\text { Amastigotes } \\
\mathrm{CC}_{50}(\mu \mathrm{g} / \mathrm{mL}) \\
(95 \% \text { C.I. })^{\mathrm{a}}\end{array}$ & $\begin{array}{c}\text { Selectivity } \\
\text { index }(\mathrm{SI})^{\mathrm{b}}\end{array}$ \\
\hline $\begin{array}{l}\text { Methanolic } \\
\text { extract }\end{array}$ & $35.9( \pm 0.06)$ & $8.1(5.8-11.2)$ & 4.4 \\
Hexane & $22.1( \pm 1.4)$ & $6.9(4.0-11.8)$ & 3.2 \\
\hline
\end{tabular}

${ }^{\mathrm{a}}$ Data are $\mathrm{IC}_{50}$ values in $\mu \mathrm{g} / \mathrm{mL}$ and $95 \%$ confidence intervals are in brackets.

${ }^{\mathrm{b}}$ Selectivity index (SI) was calculated by dividing the $\mathrm{CC}_{50}$ of macrophages by the $\mathrm{IC}_{50}$ values of amastigotes of $L$. amazonensis.

these cells as well as their selectivity on the intracellular parasites. Compounds with selectivity index (SI) $\geq 1.0$ were considered more destructive to amastigotes of L. amazonensis than to the host cells [30]. Regarding to the selectivity of the samples, it is important to be mentioned that, despite the cytotoxic effect on macrophages, methanolic extract and hexane fraction were 4.1 and 3.6 times, respectively, more destructive to amastigote than to the host cells (Table 2).

Sitosterol was identified as one of the chemical constituents detected in methanolic extract of $L$. pubescens leaves (Figure 1) and in the hexane fraction [13]. This compound had been already shown to have antileishmanial activity by inhibiting in 70\% the promastigote forms of L. amazonensis growth at $100 \mu \mathrm{g} / \mathrm{mL}$ [31]. So, there is a possibility that sitosterol may be partially responsible for the antileishmanial activity of $L$. pubescens. However, the leishmanicidal activity against promastigotes and amastigotes of $L$. amazonensis observed in this work may be also attributed to other compounds present in active samples.

Natural extracts have been previously reported as potential sources of antiproliferative compounds [32-34]. The antiproliferative activity of methanolic extract and fractions of $L$. pubescens against HL60 e Jurkat human leukemia cells was evaluated and the results are shown in Table 1. Methanolic extract and the hexane fraction showed a moderate activity against HL60 cells while Jurkat cells were resistant to all samples tested.

Compounds like phytol and sitosterol, found in the methanolic extract and previously detected in the hexane fraction [13] may be, at least in part, responsible for the antiproliferative activity against HL60 cell line. Studies have demonstrated that sitosterol showed a highest antiproliferative activity against human tumor cells [35]. Results suggested that sitosterol induces endoreduplication by promoting spindle microtubule dynamics through the Bcl-2 and PI3 K/Akt signaling pathways [36]. Other studies have also shown the cytotoxicity of phytol on cancer cell lines as HL60 [37] which was due to induction of apoptosis [38].

Antibacterial activity of $L$. pubescens samples was evaluated by MIC determination for some bacteria commonly known to cause human infection. Results are reported in Table 3. MIC values ranged from $125 \mu \mathrm{g} / \mathrm{mL}$ to $1000 \mu \mathrm{g} / \mathrm{mL}$. Ethyl acetate and hydromethanolic fractions showed the highest antibacterial activity against gram-negative bacteria Enterobacter cloacae $(125 \mu \mathrm{g} / \mathrm{mL})$. Therefore, the overall antibacterial activity was not very significative. Among the seven bacterial strains tested, the gram-negative bacterium $E$. cloacae was the most sensitive to the extract and fractions, while $S$. aureus and Enterococcus faecalis were the most resistant. Previous works have demonstrated that sitosterol is inactive for several bacteria strains as some evaluated in this study $[39,40]$. Phytol was shown to inhibit the growth of $S$. aureus [41]. However this activity was not observed in this work.

\section{Conclusions}

The results obtained represent a worthwhile contribution to biological and chemical knowledge of a traditional medicinal 
TABLE 3: Antimicrobial activity of the methanolic extract and fractions of L. pubescens.

\begin{tabular}{|c|c|c|c|c|c|c|c|}
\hline \multicolumn{8}{|c|}{$\mathrm{MIC}^{\mathrm{a}}(\mathrm{mg} / \mathrm{mL})$} \\
\hline Samples & SA & PA & $\mathrm{SD}$ & ST & $\mathrm{EC}$ & EN & $\mathrm{EF}$ \\
\hline Methanolic extract & 1 & 0.5 & 0.5 & 0.5 & 1 & 0.5 & 1 \\
\hline Hexane & 1 & 1 & 0.5 & 0.5 & 1 & 1 & 1 \\
\hline Ethyl acetate & 1 & 0.5 & 0.5 & 0.5 & 0.5 & 0.125 & 1 \\
\hline Hydromethanol & 1 & 0.5 & 0.250 & 0.250 & 0.5 & 0.125 & 1 \\
\hline Chloramphenicol $^{\mathrm{b}}$ & 0.02 & $>0.1$ & 0.05 & 0.003 & 0.001 & 0.003 & 0.03 \\
\hline
\end{tabular}

Microorganisms: SA: Staphylococcus aureus; PA: Pseudomonas aeruginosa; SD: Shigella dysenteriae; ST: Salmonella typhimurium; EC: Escherichia coli; EN: Enterobacter cloacae; EF: Enterococcus faecalis.

${ }^{a}$ MIC: minimum inhibitory concentration.

${ }^{\mathrm{b}}$ Control drug.

plant from Brazilian flora and indicated that Lacistema pubescens is a great candidate for further activity-guided fractionation in the search for new active therapeutic compounds.

\section{Conflict of Interests}

The authors declare that there is no conflict of interests regarding the publication of this paper.

\section{Acknowledgments}

The authors are grateful to Fundação de Amparo a Pesquisa do Estado de Minas Gerais (FAPEMIG) and Universidade Federal de Juiz de Fora (UFJF), Brazil, for financial support, to Dr. Fatima Regina Salimena for the botanical identification of species and to Delfino Antonio Campos for technical assistance.

\section{References}

[1] United Kingdom: Lacistemataceae Holistic Database, 2008, http://www.lacistemataceae.org/.

[2] L. C. Di Stasi and C. A. Hiruma-Lima, Plantas Medicinais na Amazônia e na Mata Atlântica, Edited by: J. H. Gutierre, Editora UNESP, 2nd edition, 2002.

[3] W. L. Barbosa and L. N. Pinto, "Documentação e valorização da fitoterapia tradicional Kayapó nas aldeias A’Ukre e Pykanusudeste do Pará," Revista Brasileira de Farmacognosia, vol. 13, pp. 47-49, 2003.

[4] V. Roumy, G. Garcia-Pizango, A. L. Gutierrez-Choquevilca et al., "Amazonian plants from Peru used by Quechua and Mestizo to treat malaria with evaluation of their activity," Journal of Ethnopharmacology, vol. 112, no. 3, pp. 482-489, 2007.

[5] M. E. Wall, M. C. Wani, T. J. Hughes, and H. Taylor, "Plant antimutagenic agents, 1 . General bioassay and isolation procedures," Journal of Natural Products, vol. 51, no. 5, pp. 866-873, 1988.

[6] D. G. Agripino, M. E. Lima, M. R. Silva et al., "Screening of Brazilian plants for antimicrobial and dnadamaging activities. I. Atlantic rain forest. Ecological station juréia-itatins," Biota Neotropica, vol. 4, pp. 1-15, 2004.

[7] I. C. Simoni, A. P. S. Manha, L. Sciessere, V. M. H. Hoe, V. H. Takinami, and M. J. Fernandes, "Evaluation of the antiviral activity of Brazilian cerrado plants against animal viruses," Virus Reviews \& Research, vol. 12, pp. 1-17, 2007.

[8] N. R. S. Silva, Florística e estrutura horizontal de uma floresta estacional semidecidual montana-mata do Juquinha de Paula, Viçosa, MG [M.S. thesis], Federal University of Viçosa, Viçosa , Brazil, 2002.

[9] C. T. Silva, G. G. Reis, M. G. F. Reis, E. Silva, and R. A. Chaves, "Avaliação temporal da florística arbórea de uma floresta secundária no município de Viçosa, Minas Gerais," Revista Árvore, vol. 28, pp. 429-441, 2004.

[10] F. A. P. Sobrinho, Conhecimento etnobotânico de mateiros residentes no entorno de Unidades de Conservação no estado do Rio de Janeiro [M.S. thesis], Instituto de Pesquisas Jardim Botânico do Rio de Janeiro, Rio de Janeiro, Brazil, 2007.

[11] E. F. S. Trindade, Atributos físico-hídricos e matéria orgânica do solo em função de sistemas de uso e manejo da vegetação secundária [M.S. thesis], University of Amazônia, 2007.

[12] J. M. Silva, E. V. S. Motta, R. Mendes, and E. Scio, "Caracterização fitoquímica e avaliação da capacidade antioxidante de diferentes partições de Lacistema pubescens Mart.," HU Revista, vol. 37, pp. 342-347, 2011.

[13] J. M. da Silva, E. V. da Motta, R. F. Mendes et al., "Antiinflammatory and antinociceptive activities of the hexane extract of lacistema pubescens mart. leaves," Pharmacologyonline, vol. 1, no. 1, pp. 9-15, 2012.

[14] T. Mosmann, "Rapid colorimetric assay for cellular growth and survival: application to proliferation and cytotoxicity assays," Journal of Immunological Methods, vol. 65, no. 1-2, pp. 55-63, 1983.

[15] CLSI-Manual Clinical and Laboratory Standards Institute; Twelth informational suplement M100-512, 2002.

[16] J. Alvar, I. D. Vélez, C. Bern et al., "Leishmaniasis worldwide and global estimates of its incidence," PLoS ONE, vol. 7, no. 5, Article ID e35671, 2012.

[17] S. L. Croft and G. H. Coombs, "Leishmaniasis-current chemotherapy and recent advances in the search for novel drugs," Trends in Parasitology, vol. 19, no. 11, pp. 502-508, 2003.

[18] L. Monzote, "Current treatment of leishmaniasis: a review," The Open Antimicrobial Agents Journal, vol. 1, pp. 9-19, 2009.

[19] P. Cos, A. J. Vlietinck, D. V. Berghe, and L. Maes, "Anti-infective potential of natural products: how to develop a stronger in vitro "proof-of-concept"', Journal of Ethnopharmacology, vol. 106, no. 3, pp. 290-302, 2006.

[20] V. A. Santos, K. M. Leite, M. Da Costa Siqueira et al., "Antiprotozoal activity of quinonemethide triterpenes from Maytenus 
ilicifolia (Celastraceae)," Molecules, vol. 18, no. 1, pp. 1053-1062, 2013.

[21] P. Houghton, R. Fang, I. Techatanawat, G. Steventon, P. J. Hylands, and C. C. Lee, "The sulphorhodamine (SRB) assay and other approaches to testing plant extracts and derived compounds for activities related to reputed anticancer activity," Methods, vol. 42, no. 4, pp. 377-387, 2007.

[22] P. Escobar, S. Matu, C. Marques, and S. L. Croft, "Sensitivities of Leishmania species to hexadecylphosphocholine (miltefosine), ET-18- $\mathrm{OCH}_{3}$ (edelfosine) and amphotericin B," Acta Tropica, vol. 81, no. 2, pp. 151-157, 2002.

[23] S. L. Croft, S. Sundar, and A. H. Fairlamb, "Drug resistance in leishmaniasis," Clinical Microbiology Reviews, vol. 19, no. 1, pp. 111-126, 2006.

[24] D. Sereno, A. Cordeiro da Silva, F. Mathieu-Daude, and A. Ouaissi, "Advances and perspectives in Leishmania cell based drug-screening procedures," Parasitology International, vol. 56, no. 1, pp. 3-7, 2007.

[25] R. H. Glew, A. K. Saha, S. Das, and A. T. Remaley, "Biochemistry of the Leishmania species," Microbiological Reviews, vol. 52, no. 4, pp. 412-432, 1988.

[26] S. M. Jeronimo and R. D. Pearson, "The Leishmania. Protozoans adapted for extracellular and intracellular survival," in Subcell Biochem, J. L. Avila and J. R. Harris, Eds., vol. 18, pp. 1-37, Plenum Press, New York, NY, USA, 1992.

[27] I. C. Ibraim, R. R. de Assis, N. L. Pessoa et al., "Two biochemically distinct lipophosphoglycans from Leishmania braziliensis and Leishmania infantum trigger different innate immune responses in murine macrophages," Parasites and Vectors, vol. 6, no. 1, article 54, 2013.

[28] A. Rochette, F. Raymond, J. Ubeda et al., "Genome-wide gene expression profiling analysis of Leishmania major and Leishmania infantum developmental stages reveals substantial differences between the two species," BMC Genomics, vol. 9, article 255, 2008.

[29] M. Vermeersch, R. I. da Luz, K. Toté, J. Timmermans, P. Cos, and L. Maes, "In vitro susceptibilities of Leishmania donovani promastigote and amastigote stages to antileishmanial reference drugs: practical relevance of stage-specific differences," Antimicrobial Agents and Chemotherapy, vol. 53, no. 9, pp. 3855-3859, 2009.

[30] E. S. Coimbra, L. M. R. Antinarelli, A. D. da Silva, M. L. F. Bispo, C. R. Kaiser, and M. V. N. De Souza, "7-chloro-4-quinolinyl hydrazones: a promising and potent class of antileishmanial compounds," Chemical Biology and Drug Design, vol. 81, no. 5, pp. 658-665, 2013.

[31] E. C. Torres-Santos, D. Lopes, R. Rodrigues Oliveira et al., "Antileishmanial activity of isolated triterpenoids from Pourouma guianensis," Phytomedicine, vol. 11, no. 2-3, pp. 114120, 2004.

[32] A. M. D’Alessandro, A. Mancini, A. R. Lizzi et al., "Crocus sativus stigma extract and its major constituent crocin possess significant antiproliferative properties against human prostate cancer," Nutrition and Cancer, vol. 65, no. 6, pp. 930-942, 2013.

[33] M. Deghrigue, A. Dellai, N. Akremi, V. Le Morvan, J. Robert, and A. Bouraoui, "Evaluation of antiproliferative and antioxidant activities of the organic extract and its polar fractions from the Mediterranean gorgonian Eunicella singularis," Environmental Toxicology and Pharmacology, vol. 36, no. 2, pp. 339346, 2013.

[34] D. Guajardo-Flores, S. O. Serna-Saldívar, and J. A. GutiérrezUribe, "Evaluation of the antioxidant and antiproliferative activities of extracted saponins and flavonols from germinated black beans (Phaseolus vulgaris L.)," Food Chemistry, vol. 141, no. 2, pp. 1497-1503, 2013.

[35] G. A. Cunha-Filho, I. S. Resck, B. C. Cavalcanti et al., "Cytotoxic profile of natural and some modified bufadienolides from toad Rhinella schneideri parotoid gland secretion," Toxicon, vol. 56, no. 3, pp. 339-348, 2010.

[36] D. Moon, M. Kim, Y. H. Choi, and G. Kim, “ $\beta$-Sitosterol induces $\mathrm{G}_{2} / \mathrm{M}$ arrest, endoreduplication, and apoptosis through the Bcl2 and $\mathrm{PI}_{3} \mathrm{~K} /$ Akt signaling pathways," Cancer Letters, vol. 264, no. 2, pp. 181-191, 2008.

[37] S. Block, C. Baccelli, B. Tinant et al., "Diterpenes from the leaves of Croton zambesicus," Phytochemistry, vol. 65, no. 8, pp. 11651171, 2004.

[38] T. Komiya, M. Kyohkon, S. Ohwaki et al., "Phytol induces programmed cell death in human lymphoid leukemia Molt 4B cells," International Journal of Molecular Medicine, vol. 4, no. 4, pp. 377-380, 1999.

[39] N. R. Sanches, D. A. G. Cortez, M. S. Schiavini, C. V. Nakamura, and B. P. Dias Filho, "An evaluation of antibacterial activities of Psidium guajava (L.)," Brazilian Archives of Biology and Technology, vol. 48, no. 3, pp. 429-436, 2005.

[40] H. Liu, K. Wang, J. Zhao, M. Wang, and L. Zhou, "Secondary metabolites from Halostachys caspica and their antimicrobial and antioxidant activities," Records of Natural Products, vol. 6, no. 1, pp. 57-61, 2012.

[41] Y. Inoue, T. Hada, A. Shiraishi, K. Hirose, H. Hamashima, and S. Kobayashi, "Biphasic effects of geranylgeraniol, teprenone, and phytol on the growth of Staphylococcus aureus," Antimicrobial Agents and Chemotherapy, vol. 49, no. 5, pp. 1770-1774, 2005. 

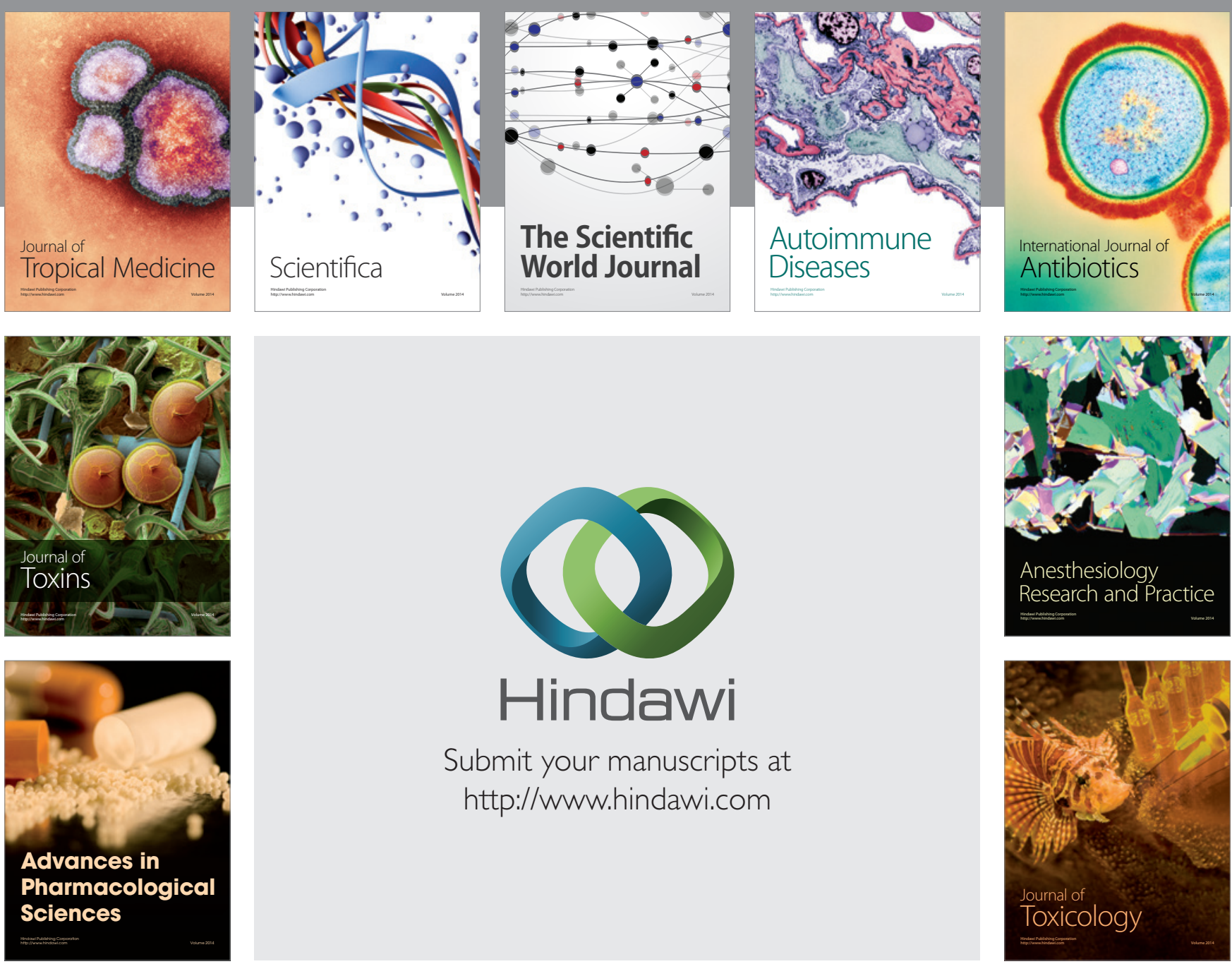

\section{Hindawi}

Submit your manuscripts at

http://www.hindawi.com
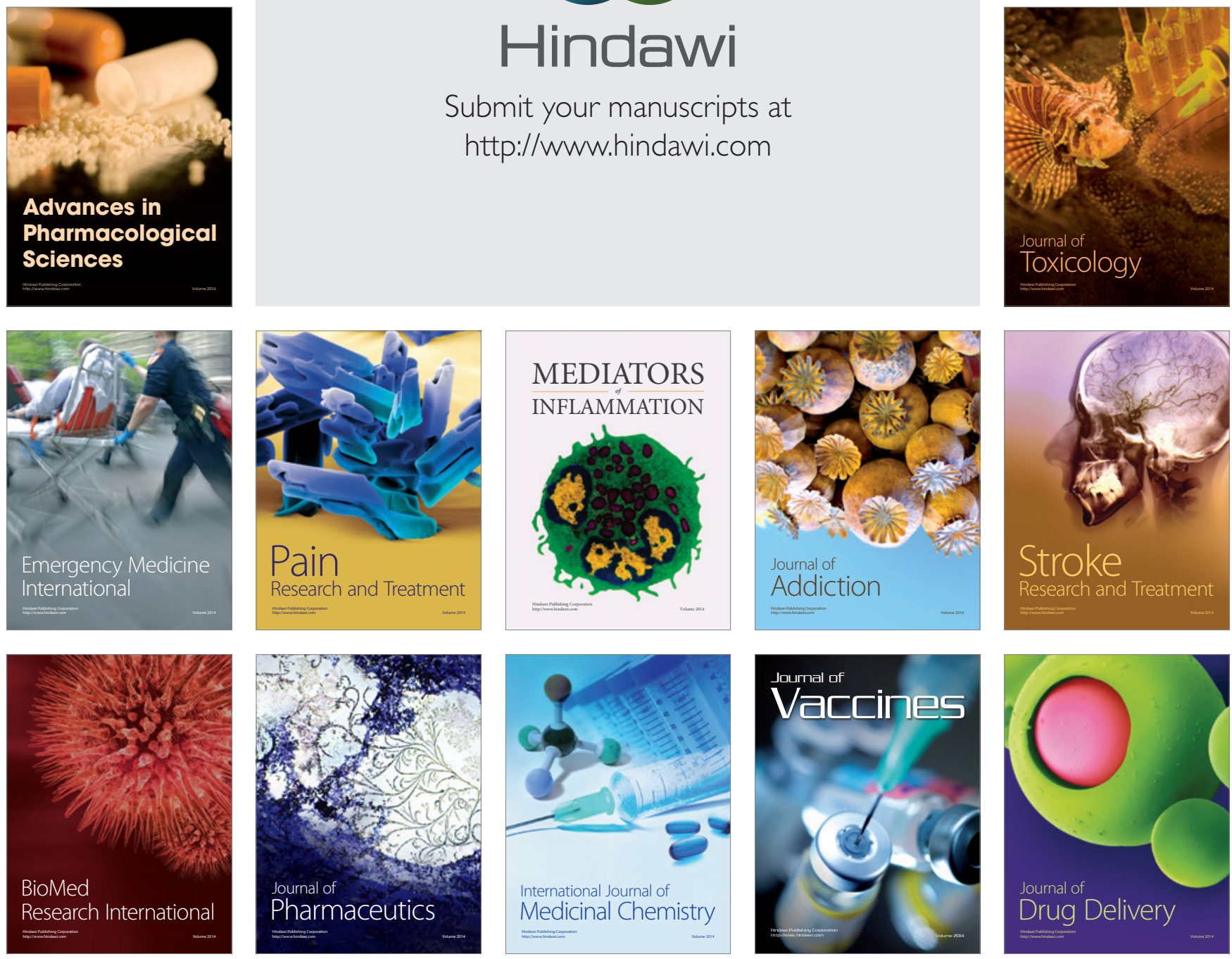